\title{
ARTIST STATEMENT
}

I have always had a connection to my surroundings. Whether I am in the forest beneath the Elder trees, or along the Ocean with the memories of time splashing against the shore. It is in that connection that I feel the memories of my Ancestors.

When I walk on the land and come across a place that was used by my Ancestors, the voices of my Elders fill my ears. I can recall the stories shared, traditions passed down, and knowledge gathered through the years that can be found in these places. I can almost hear my Ancestors.

From historic eel weirs, encampments, foot trails, and canoe routes, being near these places strengthen that connection. To know that the very soil I walk on or the water I paddle across was used in the same way by my Family, my People, my Ancestors many moons ago; that is an amazing thing.

I was raised immersed in the traditions and culture and stories. I try to reflect those things in the work I do, whether it is with raw materials or acrylics on canvas. For our next generations, capturing that knowledge and sharing it, passing it along is as important as the preservation and protection of artifacts and culturally significant sites.

Living in the district of Kespukwitk and knowing the history we have here, a continuation of time periods not broken up, gives me a sense of pride. We have such a culturally rich landscape, full of memory that through stories must be told.

The background of the painting I have created for the cover of this book represents both the sunrise and sunset. The circle of days that are never-ending as they are life.

The figure is loosely based on the petroglyph images of the female (the tear-drop shaped head is my signature design when I do these images). I chose the female as the Mi'kmaq, like many Indigenous nations, are matriarchal, following the female line, but also looking to the females to carry on many of the traditions for the generations to come. Plus, I see her as a keeper of the spark of life ... the one who carries that spark/ember in a shell for the duration of a trip by canoe and on foot from the interior of Kejimkujik to the coastal lands of Port Joli, where these artifacts have been found. The honour and responsibility placed on her are both tiring and exhilarating.

There are seven layers of land represented, using the sacred number of seven. They also represent the seven directions (north, south, east, west, sky, earth, and self). 
The layers of land show the plants above the first layer of soil and the root structures of plant life through time, the shifting of time as the land moves in a motion only controlled by the land, the layers of soil, the energy in the soil, the memories and artifacts it contains, the ancestors that lay beneath the surface who allow us a pathway so that we can mentally, physically, spiritually move forward.

The female wears one feather. This represents the eastern direction, where the sun rises. This is the birth of knowledge's direction. Where dreams begin, where curiosity grows from.

The colours on the female figure blend with the earth colours (soil colors) as we are connected to the earth in so many ways.

We are walking ancestors.

Melissa Labrador

October 2020 